\title{
The Patient Protection and Affordable Care Act
}

All CMS Provisions -- As of December 10, 2010

\begin{tabular}{|c|c|c|c|}
\hline $\begin{array}{c}\text { Section } \\
\text { of the } \\
\text { Law }\end{array}$ & Subject & Implementing Document & $\begin{array}{c}\text { Release } \\
\text { Date }\end{array}$ \\
\hline $\begin{array}{r}1001 \\
\text { (1of9) }\end{array}$ & $\begin{array}{l}\text { Amendments to the Public Health Service Act -- } 2711 \text {-- No lifetime or annual limits - } \\
\text { Prohibits all loans from establishing lifetime or unreasonable annual limits on the } \\
\text { dollar value of benefits. } \\
\text { With respect to plan years beginning prior to January 1, 2014, a group health plan and } \\
\text { a health insurance issuer offering group or individual health insurance coverage may } \\
\text { only establish a restricted annual limit on the dollar value of benefits for any } \\
\text { participant or beneficiary with respect to the scope of benefits that are essential health } \\
\text { benefits as determined by the Secretary. } \\
\text { Requires plans to provide a summary of coverage to applicants and policyholders or } \\
\text { certificate holders, as well as to enrollees. } \\
\text { RB -- } 2301 \text {-- Insurance Reforms -- Extends the prohibition of lifetime limits and a } \\
\text { requirement to provide coverage for non-dependent children up to age } 26 \text { to all } \\
\text { existing health insurance plans starting six months after enactment. For group health } \\
\text { plans, prohibits pre-existing condition exclusions in } 2014 \text {, restricts annual limits } \\
\text { beginning six months after enactment, and prohibits them starting in } 2014 \text {. }\end{array}$ & $\begin{array}{l}\text { Regulation-Omnibus Health } \\
\text { Insurance Market Interim Final } \\
\text { Rule (Preventive Services) } \\
\text { Guidance }\end{array}$ & 5-10-10 \\
\hline
\end{tabular}




\section{The Patient Protection and Affordable Care Act}

All CMS Provisions -- As of December 10, 2010

\begin{tabular}{|c|c|c|c|}
\hline $\begin{array}{l}\text { Section } \\
\text { of the } \\
\text { Law }\end{array}$ & Subject & Implementing Document & $\begin{array}{c}\text { Release } \\
\text { Date }\end{array}$ \\
\hline $\begin{array}{c}1001 \\
\text { (2of9) }\end{array}$ & $\begin{array}{l}\text { Amendments to the Public Health Service Act - } \mathbf{2 7 1 2} \text {--Prohibition on rescissions -- } \\
\text { Prohibits all plans from rescinding coverage except in instances of fraud or } \\
\text { misrepresentation. } \\
\text { RB -- } 2301 \text {-- Insurance Reforms -- Extends the prohibition on rescissions and a } \\
\text { requirement to provide coverage for non-dependent children up to age } 26 \text { to all } \\
\text { existing health insurance plans starting six months after enactment. }\end{array}$ & $\begin{array}{l}\text { Regulation-Omnibus Health } \\
\text { Insurance Market Interim Final } \\
\text { Rule (Preventive Services) } \\
\text { Guidance }\end{array}$ & 5-10-10 \\
\hline $\begin{array}{c}1001 \\
\text { (3of9) }\end{array}$ & $\begin{array}{l}\text { Amendments to the Public Health Service Act -- } 2713 \text {-- Coverage of preventive health } \\
\text { services -- Requires all plans to cover preventive services and immunizations } \\
\text { recommended by the U.S. Preventive Services Task Force and the CDC, and certain } \\
\text { child preventive services recommended by the Health Resources and Services } \\
\text { Administration, without any cost-sharing. }\end{array}$ & $\begin{array}{l}\text { Regulation-Omnibus Health } \\
\text { Insurance Market Interim Final } \\
\text { Rule (Preventive Services) } \\
\text { Guidance }\end{array}$ & 7-14-10 \\
\hline $\begin{array}{c}1001 \\
\text { (4of9) }\end{array}$ & $\begin{array}{l}\text { Amendments to the Public Health Service Act -- } 2714 \text {-- Extension of dependent } \\
\text { coverage -- Requires all plans offering dependent coverage to allow unmarried } \\
\text { individuals until age } 26 \text { to remain on their parents' health insurance. } \\
\text { RB -- } 1004 \text {-- Income definitions -- Extends the exclusion from gross income for } \\
\text { employer provided health coverage for adult children up to age } 26 \text {. }\end{array}$ & $\begin{array}{l}\frac{\text { Regulation-Omnibus Health }}{\text { Insurance Market Interim Final }} \\
\text { Rule (Coverage Up to Age 26) } \\
\text { Guidance }\end{array}$ & 5-10-10 \\
\hline $\begin{array}{c}1001 \\
\text { (5of9) }\end{array}$ & $\begin{array}{l}\text { Amendments to the Public Health Service Act -- } 2715 \text {--Development and } \\
\text { utilization of uniform explanation of coverage documents and standardized } \\
\text { definitions -- Requires the Secretary to develop standards for use by health } \\
\text { insurers in compiling and providing an accurate summary of benefits and } \\
\text { explanation of coverage. The standards must be in a uniform format, using }\end{array}$ & $\begin{array}{l}\text { Regulation-Omnibus Health } \\
\text { Insurance Market Interim Final } \\
\text { Rule (Coverage Up to Age 26) }\end{array}$ & $\begin{array}{l}5-10-10 \\
5-10-10\end{array}$ \\
\hline
\end{tabular}




\section{The Patient Protection and Affordable Care Act}

All CMS Provisions -- As of December 10, 2010

\begin{tabular}{|c|c|c|c|}
\hline $\begin{array}{l}\text { Section } \\
\text { of the } \\
\text { Law }\end{array}$ & Subject & Implementing Document & $\begin{array}{c}\text { Release } \\
\text { Date }\end{array}$ \\
\hline & $\begin{array}{l}\text { language that is easily understood by the average enrollee, and must include } \\
\text { uniform definitions of standard insurance and medical terms. The explanation must } \\
\text { also describe any cost-sharing, exceptions, reductions, and limitations on coverage, } \\
\text { and examples to illustrate common benefits scenarios. }\end{array}$ & Guidance & \\
\hline $\begin{array}{c}1001 \\
(6 \circ f 9)\end{array}$ & $\begin{array}{l}\text { Amendments to the Public Health Service Act - } 2716 \text {-- Prohibition on discrimination } \\
\text { in favor of highly compensated individuals -- Employers that provide health coverage } \\
\text { will be prohibited from limiting eligibility for coverage based on the wages or salaries } \\
\text { of full-time employees. Also, prohibits the required collection of data from employees } \\
\text { (specifically gun ownership). }\end{array}$ & $\begin{array}{l}\frac{\text { Regulation-Omnibus Health }}{\text { Insurance Market Interim Final }} \\
\frac{\text { Rule (Coverage Up to Age 26) }}{\text { Guidance }}\end{array}$ & $5-10-10$ \\
\hline $\begin{array}{c}1001 \\
\text { (7of9) }\end{array}$ & $\begin{array}{l}\text { Amendments to the Public Health Service Act -- } \mathbf{2 7 1 7} \text {-- Ensuring quality of care -- } \\
\text { Requires the Secretary to develop guidelines for use by health insurers to report } \\
\text { information on initiatives and programs that improve health outcomes through the } \\
\text { use of care coordination and chronic disease management, prevent hospital } \\
\text { readmissions and improve patient safety, and promote wellness and health. }\end{array}$ & $\begin{array}{l}\text { Regulation-Omnibus Health } \\
\text { Insurance Market Interim Final } \\
\text { Rule (Preventive Services) } \\
\text { Guidance }\end{array}$ & $5-10-10$ \\
\hline $\begin{array}{c}1001 \\
\text { (8of9) }\end{array}$ & $\begin{array}{l}\text { Amendments to the Public Health Service Act -- } \mathbf{2 7 1 8} \text {-- Bringing down the cost of } \\
\text { health care coverage -- Requires the Secretary promulgate regulations for } \\
\text { enforcing the provisions under this section. Health insurance companies will be } \\
\text { required to report publicly the ratio of the incurred loss (or incurred claims) plus } \\
\text { the loss adjustment expense (or change in contract reserves) to earned premiums } \\
\text { including the percentage of total premium revenue that is expended on clinical } \\
\text { services, and quality rather than administrative costs. Health insurance companies } \\
\text { will be required to refund each enrollee by the amount by which premium revenue } \\
\text { expended by the health insurer for non-claims costs exceeds } 20 \text { percent in the }\end{array}$ & $\begin{array}{l}\frac{\text { Regulation-Omnibus Health }}{\text { Insurance Market Interim Final }} \\
\underline{\text { Rule (Coverage Up to Age 26) }} \\
\text { Notice--Request for Information } \\
\text { on Medical Loss Ratio }\end{array}$ & $4-12-10$ \\
\hline
\end{tabular}




\section{The Patient Protection and Affordable Care Act}

All CMS Provisions -- As of December 10, 2010

\begin{tabular}{|c|c|c|c|}
\hline $\begin{array}{l}\text { Section } \\
\text { of the } \\
\text { Law }\end{array}$ & Subject & Implementing Document & $\begin{array}{c}\text { Release } \\
\text { Date }\end{array}$ \\
\hline & $\begin{array}{l}\text { group market and } 25 \text { percent in the individual market. The requirement to provide } \\
\text { a refund expires on December } 31,2013 \text {, but the requirement to report percentages } \\
\text { continues. } \\
\text { Require the Secretary make reports received under this section available to the } \\
\text { public on the HHS website. }\end{array}$ & & \\
\hline 1101 & $\begin{array}{l}\text { Immediate access to insurance for people with a preexisting condition -- Enacts a } \\
\text { temporary insurance program with financial assistance for those who have been } \\
\text { uninsured for several months and have a pre-existing condition. Ensures premium rate } \\
\text { limits for the newly insured population. Provides up to } \$ 5 \text { billion for this program, } \\
\text { which terminates when the American Health Benefit Exchanges are operational in } \\
\text { 2014. Also establishes a transition to the Exchanges for eligible individuals. }\end{array}$ & $\begin{array}{l}\text { High Risk Pools; Interim Final } \\
\text { Rule } \\
\text { Guidance -- Letter to States }\end{array}$ & $\begin{array}{l}5-10-10 \\
4-30-10\end{array}$ \\
\hline 1102 & $\begin{array}{l}\text { Reinsurance for early retirees -- Establishes a temporary reinsurance program to } \\
\text { provide reimbursement to participating employment-based plans for part of the cost } \\
\text { of providing health benefits to retirees (age } 55-64 \text { ) and their families. The program } \\
\text { reimburses participating employment-based plans for } 80 \text { percent of the cost of } \\
\text { benefits provided per enrollee in excess of } \$ 15,000 \text { and below } \$ 90,000 \text {. The plans are } \\
\text { required to use the funds to lower costs borne directly by participants and } \\
\text { beneficiaries, and the program incentivizes plans to implement programs and } \\
\text { procedures to better manage chronic conditions. The act appropriates } \$ 5 \text { billion for } \\
\text { this fund and funds are available until expended. }\end{array}$ & $\begin{array}{l}\text { Regulation -- Reinsurance } \\
\text { Program for Retirees Interim } \\
\text { Final Rule }\end{array}$ & $05-04-10$ \\
\hline
\end{tabular}




\section{The Patient Protection and Affordable Care Act}

All CMS Provisions -- As of December 10, 2010

\begin{tabular}{|c|c|c|c|}
\hline $\begin{array}{l}\text { Section } \\
\text { of the } \\
\text { Law }\end{array}$ & Subject & Implementing Document & $\begin{array}{c}\text { Release } \\
\text { Date }\end{array}$ \\
\hline 1003 & $\begin{array}{l}\text { Ensuring that consumers get value for their dollars -- For plan years beginning in } 2010 \text {, } \\
\text { the Secretary and States will establish a process for the annual review of increases in } \\
\text { premiums for health insurance coverage. Requires States to make recommendations to } \\
\text { their Exchanges about whether health insurance issuers should be excluded from } \\
\text { participation in the Exchanges based on unjustified premium increases. Provides } \$ 250 \\
\text { million in funding to States from } 2010 \text { until } 2014 \text { to assist States in reviewing and, if } \\
\text { appropriate under State law, approving premium increases for health insurance } \\
\text { coverage and in providing information and recommendations to the Secretary. }\end{array}$ & $\begin{array}{l}\text { Regulation -- Omnibus Health } \\
\text { Insurance Market Interim Final } \\
\text { Rule(Part 1) } \\
\text { Notice--Request for Information } \\
\text { on Premium Rate Review } \\
\text { Guidance }\end{array}$ & $\begin{array}{l}4-30-10 \\
4-30-10\end{array}$ \\
\hline 1103 & $\begin{array}{l}\text { Immediate information that allows consumers to identify affordable coverage } \\
\text { options -- Establishes an Internet portal for beneficiaries to easily access affordable } \\
\text { and comprehensive coverage options. This information will include eligibility, } \\
\text { availability, premium rates, cost sharing, and the percentage of total premium } \\
\text { revenues spent on health care, rather than administrative expenses, by the issuer } \\
\text { [(including Medicaid) in the State shall be available to small businesses and shall } \\
\text { contain information on coverage options.] } \\
\text { Clarifies that reinsurance for early retirees applies to plans sponsored by State and } \\
\text { local governments for their employees. }\end{array}$ & $\begin{array}{l}\text { Creation of Website } \\
\text { Regulation -- Web Portal for } \\
\text { Private Plan and Medicaid/CHIP } \\
\text { Data Interim Final Rule with } \\
\text { Comment }\end{array}$ & $\begin{array}{l}-1-10 \\
4-30-10\end{array}$ \\
\hline $\begin{array}{c}1201 \\
\text { (4of8) }\end{array}$ & $\begin{array}{l}\text { Amendment to the Public Health Service Act -- Sec. } 2704 \text {-- Prohibition of preexisting } \\
\text { condition exclusions or other discrimination based on health status -- No group health } \\
\text { plan or insurer offering group or individual coverage may impose any pre-existing } \\
\text { condition exclusion or discriminate against those who have been sick in the past. }\end{array}$ & $\begin{array}{l}\text { Regulation- Omnibus Health } \\
\text { Insurance Market Interim Final } \\
\text { Rule (Part1) } \\
\text { Guidance }\end{array}$ & 5-10-10 \\
\hline
\end{tabular}




\section{The Patient Protection and Affordable Care Act}

All CMS Provisions -- As of December 10, 2010

\begin{tabular}{|c|c|c|c|}
\hline $\begin{array}{l}\text { Section } \\
\text { of the } \\
\text { Law }\end{array}$ & Subject & Implementing Document & $\begin{array}{c}\text { Release } \\
\text { Date }\end{array}$ \\
\hline $\begin{array}{c}1201 \\
\text { (5of8) }\end{array}$ & $\begin{array}{l}\text { Amendment to the Public Health Service Act -- Sec. } 2705 \text {-- Prohibiting discrimination } \\
\text { against individual participants and beneficiaries based on health status -- No group } \\
\text { health plan or insurer offering group or individual coverage may set eligibility rules } \\
\text { based on health status, medical condition, claims experience, receipt of health care, } \\
\text { medical history, genetic information, evidence of insurability - including acts of } \\
\text { domestic violence or disability. Permits employers to vary insurance premiums by as } \\
\text { much as } 30 \text { percent for employee participation in certain health promotion and disease } \\
\text { prevention programs. Authorizes a 10-State demonstration to apply such a program in } \\
\text { the individual market. }\end{array}$ & $\begin{array}{l}\text { Regulation- Omnibus Health } \\
\text { Insurance Market Interim Final } \\
\text { Rule (Part 1) } \\
\text { Guidance }\end{array}$ & $5-10-10$ \\
\hline 1251 & $\begin{array}{l}\text { Preservation of right to maintain existing coverage -- Allows any individual enrolled in } \\
\text { any form of health insurance to maintain their coverage as it existed on the date of } \\
\text { enactment. }\end{array}$ & $\begin{array}{l}\text { Regulation- Omnibus Health } \\
\text { Insurance Market Interim Final } \\
\text { Rule (Part 2) }\end{array}$ & 6-14-10 \\
\hline 1303 & $\begin{array}{l}\text { Special rules -- Voluntary Choice of Coverage of Abortion Services -- } 10104 \text {-- Affirms that } \\
\text { States may prohibit abortion coverage in qualified health plans offered through an Exchange in } \\
\text { such State if such State enacts a law to provide for such prohibition. } \\
\text { Allows plans to elect whether or not to cover abortion. Requires a segregation of funds for } \\
\text { subsidy-eligible individuals in plans that cover abortions for which the expenditure of Federal } \\
\text { funds appropriated for HHS is not permitted. Subsidy-eligible individuals would make two } \\
\text { payments, with one going to an allocation account to be used exclusively for payment of such } \\
\text { services. Requires State insurance commissioners to ensure compliance with the requirement } \\
\text { to segregate federal funds in accordance with generally accepted accounting requirements and } \\
\text { guidance from OMB and GAO. Plans would be required to include in their benefit descriptions } \\
\text { whether or not they cover abortion, as they will do for all other benefits. Replaces provider } \\
\text { conscience protections with new conscience language that would prohibit qualified health plans }\end{array}$ & $\begin{array}{l}\text { Regulation-Omnibus Health } \\
\text { Insurance Market Interim Final } \\
\text { Rule (Part1) } \\
\text { Guidance }\end{array}$ & $5-10-10$ \\
\hline
\end{tabular}




\section{The Patient Protection and Affordable Care Act}

All CMS Provisions -- As of December 10, 2010

\begin{tabular}{|c|c|c|c|}
\hline $\begin{array}{l}\text { Section } \\
\text { of the } \\
\text { Law }\end{array}$ & Subject & Implementing Document & $\begin{array}{c}\text { Release } \\
\text { Date }\end{array}$ \\
\hline & $\begin{array}{l}\text { from discriminating against any individual health care provider or health care facility because of } \\
\text { its unwillingness to provide, pay for, provide coverage of, or refer for abortions. Federal and } \\
\text { State laws regarding abortion are not preempted. }\end{array}$ & & \\
\hline $\begin{array}{c}2001 \\
\text { (2of3) }\end{array}$ & $\begin{array}{l}\text { Medicaid coverage for the lowest income populations -- Eligibility --Eligible } \\
\text { individuals include: all non-elderly, non-pregnant individuals who are not entitled to } \\
\text { Medicare (e.g., childless adults and certain parents). Creates a new mandatory } \\
\text { Medicaid eligibility category for all such "newly-eligible" individuals with income at or } \\
\text { below } 133 \text { percent of the Federal Poverty Level (FPL) beginning January 1, 2014. Also, } \\
\text { as of January 1,2014, the mandatory Medicaid income eligibility level for children ages } \\
\text { six to } 19 \text { changes from } 100 \text { percent FPL to } 133 \text { percent FPL. States have the option to } \\
\text { provide Medicaid coverage to all non-elderly individuals above } 133 \text { percent of FPL } \\
\text { through a State plan amendment. }\end{array}$ & $\begin{array}{l}\text { SMD Letter } \\
\text { SMD Letter } \\
\text { Enhanced Funding Proposed Rule } \\
\text { (CMS-2346-P) }\end{array}$ & $\begin{array}{r}04 / 09 / 2010 \\
7 / 2 / 2010 \\
11 / 18 / 10\end{array}$ \\
\hline 2302 & $\begin{array}{l}\text { Concurrent care for children -- Allows children who are enrolled in either Medicaid } \\
\text { or CHIP to receive hospice services without foregoing curative treatment related to } \\
\text { a terminal illness. }\end{array}$ & SMD Letter & $09 / 09 / 2010$ \\
\hline $\begin{array}{c}2303 \\
\text { (1of2) }\end{array}$ & $\begin{array}{l}\text { State eligibility option for family planning services -- Adds a new optional } \\
\text { categorically-needy eligibility group to Medicaid comprised of (1) non-pregnant } \\
\text { individuals with income up to the highest level applicable to pregnant women } \\
\text { covered under Medicaid or CHIP, and ( } 2 \text { ) individuals eligible under the standards } \\
\text { and processes of existing section } 1115 \text { waivers that provide family planning } \\
\text { services and supplies. Benefits would be limited to family planning services and } \\
\text { supplies, including related medical diagnostic and treatment services. }\end{array}$ & $\begin{array}{l}\text { SMD Letter } \\
\text { SMD Letter }\end{array}$ & 7/2/2/2010 \\
\hline
\end{tabular}




\section{The Patient Protection and Affordable Care Act}

All CMS Provisions -- As of December 10, 2010

\begin{tabular}{|c|c|c|c|}
\hline $\begin{array}{l}\text { Section } \\
\text { of the } \\
\text { Law }\end{array}$ & Subject & Implementing Document & $\begin{array}{c}\text { Release } \\
\text { Date }\end{array}$ \\
\hline $\begin{array}{l}2402 \\
(2 o f 2)\end{array}$ & $\begin{array}{l}\text { Removal of barriers to providing home and community-based services -- Removes } \\
\text { barriers to providing HCBS by giving States the option to provide more types of } \\
\text { HCBS through a State plan amendment to individuals with higher levels of need, } \\
\text { rather than through a waiver, and to extend full Medicaid benefits to individuals } \\
\text { receiving HCBS under a State plan amendment. }\end{array}$ & $\underline{\text { SMD Letter }}$ & $08 / 6 / 2010$ \\
\hline 2403 & $\begin{array}{l}\text { Money Follows the Person Rebalancing Demonstration -- Extends the Money } \\
\text { Follows the Person Rebalancing Demonstration through September 30, } 2016 \text { and } \\
\text { changes the eligibility rules for individuals to participate in the demonstration } \\
\text { project by requiring that individuals reside in an inpatient facility for not less than } \\
90 \text { consecutive days. }\end{array}$ & $\begin{array}{l}\text { SMD Letter } \\
\text { Issue Grant Solicitations } \\
\text { Award Planning Grant }\end{array}$ & $\begin{array}{l}6 / 22 / 2010 \\
7 / 26 / 2010 \\
9 / 28 / 2010\end{array}$ \\
\hline $\begin{array}{l}2501 \\
(10 f 2)\end{array}$ & $\begin{array}{l}\text { Prescription drug rebates -- The flat rebate for single source and innovator } \\
\text { multiple source outpatient prescription drugs would increase from } 15.1 \text { percent to } \\
23.1 \text { percent, except the rebate for clotting factors and outpatient drugs approved } \\
\text { by the Food and Drug Administration exclusively for pediatric indications would } \\
\text { increase to } 17.1 \text { percent. The basic rebate percentage for multi-source, non- } \\
\text { innovator drugs would increase from } 11 \text { percent to } 13 \text { percent. Drug } \\
\text { manufacturers would also be required to pay rebates for drugs dispensed to } \\
\text { Medicaid beneficiaries who receive care from a Medicaid managed care } \\
\text { organization (MCO). Total rebate liability would be limited to } 100 \text { percent of the } \\
\text { average manufacturer price (AMP). Additional revenue generated by these } \\
\text { increases will be remitted to the federal government. }\end{array}$ & $\underline{\text { SMD Letter }}$ & $04 / 22 / 2010$ \\
\hline 2501 & $\begin{array}{l}\text { Prescription drug rebates -- } R B \text {-- } 1206 \text {-- Drug rebates for new formulations of } \\
\text { existing drugs -- For purposes of applying the additional rebate, narrows the }\end{array}$ & $\underline{\text { SMD Letter }}$ & $04 / 22 / 2010$ \\
\hline
\end{tabular}




\section{The Patient Protection and Affordable Care Act}

All CMS Provisions -- As of December 10, 2010

\begin{tabular}{|c|c|c|c|}
\hline $\begin{array}{l}\text { Section } \\
\text { of the } \\
\text { Law }\end{array}$ & Subject & Implementing Document & $\begin{array}{c}\text { Release } \\
\text { Date }\end{array}$ \\
\hline (2of2) & $\begin{array}{l}\text { definition of a new formulation of a drug to a line extension of a single source or } \\
\text { innovator multiple source drug that is an oral solid dosage form of the drug. }\end{array}$ & & \\
\hline 2902 & $\begin{array}{l}\text { Elimination of sunset for reimbursement for all Medicare Part B services } \\
\text { furnished by certain Indian hospitals and clinics -- Removes the sunset provision, } \\
\text { allowing IHS and I/T/U services to continue to be reimbursed by Medicare Part B. }\end{array}$ & $\begin{array}{l}\text { Guidance -- JSM } \\
\text { Federal Register Notice -- } \\
\text { Updates to the OPPS and ASC } \\
\text { Payment system Resulting from } \\
2010 \text { HCR provisions }\end{array}$ & $3 / 29 / 2010$ \\
\hline $\begin{array}{c}3002 \\
(1 \mathrm{of} 4)\end{array}$ & $\begin{array}{l}\text { Improvements to the physician quality reporting initiative -- Extends through } \\
2014 \text { payments under the PQRI program, which provide incentives to physicians } \\
\text { who report quality data to Medicare. Creates appeals and feedback processes for } \\
\text { participating professionals in PQRI. Establishes a participation pathway for } \\
\text { physicians completing a qualified Maintenance of Certification program with their } \\
\text { specialty board of medicine. }\end{array}$ & $\begin{array}{l}\text { Regulation -- Physician Fee } \\
\text { Schedule Proposed Rule } \\
\text { Regulation - Physician Fee } \\
\text { Schedule Final Rule } \\
\text { Guidance - Change Request }\end{array}$ & $\begin{array}{l}06 / 25 / 2010 \\
11 / 2 / 2010 \\
11 / 2 / 2010\end{array}$ \\
\hline $\begin{array}{c}3002 \\
(30 f 4)\end{array}$ & $\begin{array}{l}\text { Improvements to the physician quality reporting initiative -- Requires the } \\
\text { Secretary establish and have in place an informal process for eligible professionals } \\
\text { to seek a review of the determination that an eligible professional did not } \\
\text { satisfactorily submit data on quality measures. }\end{array}$ & $\begin{array}{l}\text { Regulation -- Physician Fee } \\
\text { Schedule Proposed Rule } \\
\text { Regulation - Physician Fee } \\
\text { Schedule Final Rule } \\
\text { Guidance - Change Request }\end{array}$ & $06 / 25 / 2010$ \\
\hline
\end{tabular}




\section{The Patient Protection and Affordable Care Act}

All CMS Provisions -- As of December 10, 2010

\begin{tabular}{|c|c|c|c|}
\hline $\begin{array}{l}\text { Section } \\
\text { of the } \\
\text { Law }\end{array}$ & Subject & Implementing Document & $\begin{array}{c}\text { Release } \\
\text { Date }\end{array}$ \\
\hline 3003 & $\begin{array}{l}\text { Improvements to the physician feedback program - } 1 \text {. Expands Medicare's } \\
\text { physician resource use feedback program to provide for development of } \\
\text { individualized reports by } 2012 \text {. Reports will compare utilization of physicians (or } \\
\text { groups of physicians) to other physicians who see similar patients. Reports will be } \\
\text { risk-adjusted and standardized to take into account local health care costs. } \\
\text { 2. Develop a public domain episode grouper NLT } 1 / 1 / 2012\end{array}$ & $\begin{array}{l}\text { Regulation -- Physician Fee } \\
\text { Schedule Proposed Rule } \\
\text { Regulation - Physician Fee } \\
\text { Schedule Final Rule }\end{array}$ & $11 / 2 / 2010$ \\
\hline 3027 & $\begin{array}{l}\text { Extension of gainsharing demonstration -- The Deficit Reduction Act of } 2005 \\
\text { authorized a demonstration to evaluate arrangements between hospitals and } \\
\text { physicians designed to improve the quality and efficiency of care provided to } \\
\text { beneficiaries. This provision would extend the demonstration through September } \\
\text { 30, } 2011 \text { and extend the date for the final report to Congress on the } \\
\text { demonstration to September } 30,2012 \text {. It would also authorize an additional \$1.6 } \\
\text { million in FY2010 for carrying out the demonstration. }\end{array}$ & Contract modification & 05-01-10 \\
\hline $\begin{array}{c}3102 \\
\text { (1of3) }\end{array}$ & $\begin{array}{l}\text { Extension of the work geographic index floor and revisions to the practice } \\
\text { expense geographic adjustment under the Medicare physician fee schedule -- } \\
\text { Extends a floor on geographic adjustments to the work portion of the fee schedule } \\
\text { through the end of 2010, with the effect of increasing practitioner fees in rural } \\
\text { areas. } \\
\text { RB -- } 1108 \text {-- PE GPCI ADJUSTMENT FOR } 2010 \text {-- Requires that for services } \\
\text { furnished during 2010, the employee wage and rent portions of the practice } \\
\text { expense geographic index reflect } 1 / 2 \text { of the difference between the relative costs }\end{array}$ & $\begin{array}{l}\text { Guidance - Change Request } \\
\frac{\text { Regulation -- Physician Fee }}{\text { Schedule Proposed Rule }} \\
\text { Regulation - Physician Fee } \\
\text { Schedule Final Rule }\end{array}$ & $\begin{array}{l}5 / 10 / 010 \\
06 / 25 / 2010 \\
11 / 2 / 2010\end{array}$ \\
\hline
\end{tabular}




\section{The Patient Protection and Affordable Care Act}

All CMS Provisions -- As of December 10, 2010

\begin{tabular}{|c|c|c|c|}
\hline $\begin{array}{l}\text { Section } \\
\text { of the } \\
\text { Law }\end{array}$ & Subject & Implementing Document & $\begin{array}{c}\text { Release } \\
\text { Date }\end{array}$ \\
\hline & $\begin{array}{l}\text { of employee wages and rents in each of the different fee schedule areas and the } \\
\text { national average of such employee wages and rents. }\end{array}$ & & \\
\hline $\begin{array}{c}3102 \\
\text { (2of3) }\end{array}$ & $\begin{array}{l}\text { Extension of the work geographic index floor and revisions to the practice } \\
\text { expense geographic adjustment under the Medicare physician fee schedule -- } \\
\text { Provides immediate relief to areas negatively impacted by the geographic } \\
\text { adjustment for practice expenses, and requires the Secretary of HHS to improve } \\
\text { the methodology for calculating practice expense adjustments beginning in } 2012 \text {. }\end{array}$ & $\begin{array}{l}\text { Regulation -- Physician Fee } \\
\text { Schedule Proposed Rule } \\
\text { Regulation - Physician Fee } \\
\text { Schedule Final Rule }\end{array}$ & $06 / 25 / 2010$ \\
\hline $\begin{array}{c}3102 \\
\text { (3of3) }\end{array}$ & $\begin{array}{l}\text { Extension of the work geographic index floor and revisions to the practice } \\
\text { expense geographic adjustment under the Medicare physician fee schedule -- } \\
10324 \text {-- Protections for frontier states - Provides that for purposes of payment for } \\
\text { services furnished in a frontier State on or after January } 1,2011 \text {, after calculating } \\
\text { the practice expense index the Secretary is required to increase any such index to } \\
1.00 \text { if such index would otherwise be less that } 1.00 \text {. }\end{array}$ & $\begin{array}{l}\frac{\text { Regulation -- Physician Fee }}{\text { Schedule Proposed Rule }} \\
\text { Regulation - Physician Fee } \\
\text { Schedule Final Rule }\end{array}$ & $06 / 25 / 2010$ \\
\hline 3103 & $\begin{array}{l}\text { Extension of exceptions process for Medicare therapy caps -- Extends the process } \\
\text { allowing exceptions to limitations on medically necessary therapy until December } \\
31,2010 \text {. }\end{array}$ & $\begin{array}{l}\text { Guidance - Change Request /JSM } \\
\frac{\text { Regulation -- Physician Fee }}{\text { Schedule Proposed Rule }} \\
\text { Regulation - Physician Fee } \\
\text { Schedule Final Rule }\end{array}$ & $03 / 29 / 2010$ \\
\hline
\end{tabular}




\section{The Patient Protection and Affordable Care Act}

All CMS Provisions -- As of December 10, 2010

\begin{tabular}{|c|c|c|c|}
\hline $\begin{array}{l}\text { Section } \\
\text { of the } \\
\text { Law }\end{array}$ & Subject & Implementing Document & $\begin{array}{c}\text { Release } \\
\text { Date }\end{array}$ \\
\hline 3104 & $\begin{array}{l}\text { Extension of payment for technical component of certain physician pathology } \\
\text { services -- Extends a provision that directly reimburses qualified rural hospitals for } \\
\text { certain clinical laboratory services through the end of } 2010 \text {. }\end{array}$ & $\begin{array}{l}\text { Guidance -- JSM } \\
\text { Guidance -- Change request } \\
\frac{\text { Regulation -- Physician Fee }}{\underline{\text { Schedule Proposed Rule }}} \\
\text { Regulation - Physician Fee } \\
\text { Schedule Final Rule }\end{array}$ & $\begin{array}{r}03 / 29 / 2010 \\
4 / 9 / 2010 \\
06 / 25 / 2010 \\
11 / 2 / 2010\end{array}$ \\
\hline 3105 & $\begin{array}{l}\text { Extension of ambulance add-ons -- Extends bonus payments made by Medicare for } \\
\text { ground and air ambulance services in rural and other areas 1-1-11. }\end{array}$ & $\begin{array}{l}\text { Guidance -- JSM } \\
\text { Guidance -- Change request } \\
\frac{\text { Regulation -- Physician Fee }}{\underline{\text { Schedule Proposed Rule }}} \\
\text { Regulation - Physician Fee } \\
\text { Schedule Final Rule }\end{array}$ & $\begin{array}{r}03 / 29 / 2010 \\
4 / 9 / 2010 \\
06 / 25 / 2010 \\
11 / 2 / 2010\end{array}$ \\
\hline 3106 & $\begin{array}{l}\text { Extension of certain payment rules for long-term care hospital services and of } \\
\text { moratorium on the establishment of certain hospitals and facilities -- Extends } \\
\text { Sections } 114 \text { (c) and (d) of the Medicare, Medicaid and SCHIP Extension Act of } 2007 \\
\text { by two years. }\end{array}$ & $\begin{array}{l}\text { Federal Register Notice -- } \\
\text { Changes to the IPPS Resulting } \\
\text { from } 2010 \text { HCR Provisions } \\
\text { Regulation - IPPS Final Rule }\end{array}$ & $\begin{array}{r}05 / 21 / 10 \\
07 / 30 / 2010\end{array}$ \\
\hline
\end{tabular}




\section{The Patient Protection and Affordable Care Act}

All CMS Provisions -- As of December 10, 2010

\begin{tabular}{|c|c|c|c|}
\hline $\begin{array}{l}\text { Section } \\
\text { of the } \\
\text { Law }\end{array}$ & Subject & Implementing Document & $\begin{array}{c}\text { Release } \\
\text { Date }\end{array}$ \\
\hline & 10312-- amd'd & & \\
\hline 3107 & $\begin{array}{l}\text { Extension of physician fee schedule mental health add-on -- Increases the } \\
\text { payment rate for psychiatric services by } 5 \text { percent for two years, through the end } \\
\text { of } 2010 \text {. }\end{array}$ & $\begin{array}{l}\text { Guidance -- Change request } \\
\text { Regulation -- Physician Fee } \\
\text { Schedule Proposed Rule } \\
\text { Regulation - Physician Fee } \\
\text { Schedule Final Rule }\end{array}$ & $\begin{array}{l}5 / 10 / 2010 \\
6 / 25 / 2010 \\
11 / 2 / 2010\end{array}$ \\
\hline 3108 & $\begin{array}{l}\text { Permitting physician assistants to order post-hospital extended care services -- } \\
\text { Authorizes clinical nurses or physician assistants to order skilled nursing care } \\
\text { services in the Medicare program beginning in } 2011 \text {. }\end{array}$ & $\begin{array}{l}\text { Regulation -- Physician Fee } \\
\text { Schedule Proposed Rule } \\
\text { Regulation - Physician Fee } \\
\text { Schedule Final Rule }\end{array}$ & $6 / 25 / 2010$ \\
\hline 3109 & $\begin{array}{l}\text { Exemption of certain pharmacies from accreditation requirements -- Allows } \\
\text { pharmacies which meet certain criteria, including having less than } 5 \text { percent of } \\
\text { revenues from Medicare DMEPOS billings for the past } 3 \text { years, to be exempt from } \\
\text { accreditation requirements until the Secretary of HHS develops pharmacy-specific } \\
\text { standards. }\end{array}$ & $\begin{array}{l}\text { Fact Sheet } \\
\text { Guidance -- Change Request }\end{array}$ & $7 / 7 / 2010$ \\
\hline
\end{tabular}




\section{The Patient Protection and Affordable Care Act}

All CMS Provisions -- As of December 10, 2010

\begin{tabular}{|c|c|c|c|}
\hline $\begin{array}{l}\text { Section } \\
\text { of the } \\
\text { Law }\end{array}$ & Subject & Implementing Document & $\begin{array}{c}\text { Release } \\
\text { Date }\end{array}$ \\
\hline $\begin{array}{c}3111 \\
\text { (1of2) }\end{array}$ & $\begin{array}{l}\text { Payment for bone density tests -- Restores payment for dual-energy x-ray } \\
\text { absorptiometry (DXA) services furnished during } 2010 \text { and } 2011 \text { to } 70 \text { percent of the } \\
\text { Medicare rate paid in } 2006 \text {. }\end{array}$ & $\begin{array}{l}\text { Guidance -- Change Request } \\
\text { Guidance -- Change Request } \\
\frac{\text { Regulation -- Physician Fee }}{\text { Schedule Proposed Rule }} \\
\text { Regulation - Physician Fee } \\
\text { Schedule Final Rule }\end{array}$ & $\begin{array}{c}5 / 10 / 2010 \\
5 / 28 / 10 \\
06 / 25 / 2010 \\
11 / 2 / 2010\end{array}$ \\
\hline 3112 & $\begin{array}{l}\text { Revision to the Medicare Improvement Fund-- Eliminates the remaining funds in } \\
\text { the Medicare Improvement Fund. }\end{array}$ & Self-Implementing & N/A \\
\hline 3114 & $\begin{array}{l}\text { Improved access for certified nurse-midwife services -- Increases the payment } \\
\text { rate for certified nurse midwives for covered services from } 65 \text { percent of the rate } \\
\text { that would be paid were a physician performing a service to the full rate. }\end{array}$ & $\begin{array}{l}\frac{\text { Regulation -- Physician Fee }}{\text { Schedule Proposed Rule }} \\
\text { Regulation - Physician Fee } \\
\text { Schedule Final Rule }\end{array}$ & $06 / 25 / 2010$ \\
\hline 3121 & $\begin{array}{l}\text { Extension of outpatient hold harmless provision -- Extends the existing outpatient } \\
\text { hold harmless provision through the end of FY2010 and would allow Sole } \\
\text { Community Hospitals with more than } 100 \text { beds to also be eligible to receive this } \\
\text { adjustment through the end of FY2010. }\end{array}$ & $\begin{array}{l}\text { Guidance - JSM } \\
\text { Regulation - OPPS Proposed Rule } \\
\text { Regulation - OPPS Final Rule }\end{array}$ & $\begin{array}{l}03 / 31 / 2010 \\
07 / 2 / 2010 \\
11 / 2 / 2010\end{array}$ \\
\hline
\end{tabular}




\section{The Patient Protection and Affordable Care Act}

All CMS Provisions -- As of December 10, 2010

\begin{tabular}{|c|c|c|c|}
\hline $\begin{array}{l}\text { Section } \\
\text { of the } \\
\text { Law }\end{array}$ & Subject & Implementing Document & $\begin{array}{c}\text { Release } \\
\text { Date }\end{array}$ \\
\hline 3122 & $\begin{array}{l}\text { Extension of Reasonable Cost Payment for Clinical Lab Tests Furnished to } \\
\text { Hospitals Patients in Certain Rural Areas -- Re-institutes reasonable cost payment } \\
\text { for clinical lab tests performed by hospitals with fewer than } 50 \text { beds in qualified } \\
\text { rural areas as part of their outpatient services for cost reporting periods beginning } \\
\text { on or after July } 1,2010 \text {, through June } 30,2011 \text {. This could affect services } \\
\text { performed as late as June } 30,2012 \text {. }\end{array}$ & $\begin{array}{l}\text { Guidance - JSM } \\
\text { Guidance - Change Request } \\
\frac{\text { Regulation -- Physician Fee }}{\underline{\text { Schedule Proposed Rule }}} \\
\text { Regulation - Physician Fee } \\
\text { Schedule Final Rule }\end{array}$ & $\begin{array}{r}03 / 29 / 2010 \\
4 / 2 / 2010 \\
06 / 25 / 2010 \\
11 / 2 / 2010\end{array}$ \\
\hline 3123 & $\begin{array}{l}\text { Extension of the Rural Community Hospital Demonstration Program -- Extends } \\
\text { the program for five years and expands eligible sites to additional States and } \\
\text { additional rural hospitals. } \\
\text { Sec. } 10313 \text {-- Revisions to the extension for the Rural Community Hospital } \\
\text { demonstration program -- Makes adjustments to payment levels provided within } \\
\text { the demonstration program. }\end{array}$ & $\begin{array}{l}\text { Regulation -Changes to the IPPS } \\
\text { Resulting from } 2011 \text { HCR Proposed } \\
\text { Rule } \\
\text { Regulation - IPPS Final Rule }\end{array}$ & 07/30/2010 \\
\hline 3124 & $\begin{array}{l}\text { Extension of the Medicare-dependent hospital (MDH) program -- Extends the } \\
\text { Medicare-dependent hospital program by one year through October } 1,2012 \text {. It } \\
\text { would also require HHS to study whether certain urban hospitals should qualify for } \\
\text { the MDH program. }\end{array}$ & $\begin{array}{l}\text { Regulation-Changes to the IPPS } \\
\text { Resulting from } 2011 \text { HCR Proposed } \\
\text { Rule } \\
\text { Regulation - IPPS Final Rule }\end{array}$ & $07 / 30 / 2010$ \\
\hline
\end{tabular}




\section{The Patient Protection and Affordable Care Act}

All CMS Provisions -- As of December 10, 2010

\begin{tabular}{|c|c|c|c|}
\hline $\begin{array}{l}\text { Section } \\
\text { of the } \\
\text { Law }\end{array}$ & Subject & Implementing Document & $\begin{array}{c}\text { Release } \\
\text { Date }\end{array}$ \\
\hline 3124 & $\begin{array}{l}\text { Extension of the Medicare-dependent hospital (MDH) program -- Extends the } \\
\text { Medicare-dependent hospital program by one year through October } 1,2012 \text {. It } \\
\text { would also require HHS to study whether certain urban hospitals should qualify for } \\
\text { the MDH program. }\end{array}$ & $\begin{array}{l}\text { Regulation-Changes to the IPPS } \\
\text { Resulting from } 2011 \text { HCR Proposed } \\
\text { Rule } \\
\text { Regulation - IPPS Final Rule }\end{array}$ & 07/30/2010 \\
\hline 3125 & $\begin{array}{l}\text { Temporary improvements to the Medicare inpatient hospital payment } \\
\text { adjustment for low-volume hospitals -- Expands the program providing a } \\
\text { temporary adjustment to inpatient hospital payments for certain low-volume } \\
\text { hospitals through FY2012 and would modify eligibility requirements regarding } \\
\text { distance from another facility and number of eligible discharges. } \\
\text { Sec. } 10314 \text {-- Adjustment to low-volume hospital provision -- Increases threshold } \\
\text { for eligible hospitals from 1,500 Medicare Part A discharges per year to 1,600 per } \\
\text { year. }\end{array}$ & $\begin{array}{l}\text { Regulation -Changes to the IPPS } \\
\text { Resulting from } 2011 \text { HCR Proposed } \\
\text { Rule } \\
\text { Regulation - IPPS Final Rule }\end{array}$ & $05 / 21 / 2010$ \\
\hline 3128 & $\begin{array}{l}\text { Technical correction related to critical access hospital services -- Clarifies that } \\
\text { CAHs can continue to be eligible to receive } 101 \text { percent of reasonable costs for } \\
\text { providing outpatient care regardless of eligible billing method the facility uses and } \\
\text { for providing qualifying ambulance services. (as if included in MMA of 2003) }\end{array}$ & $\begin{array}{l}\text { Regulation -Changes to the IPPS } \\
\text { Resulting from } 2011 \text { HCR Proposed } \\
\text { Rule } \\
\text { Regulation - IPPS Final Rule }\end{array}$ & $07 / 30 / 2010$ \\
\hline
\end{tabular}




\section{The Patient Protection and Affordable Care Act}

All CMS Provisions -- As of December 10, 2010

\begin{tabular}{|c|c|c|c|}
\hline $\begin{array}{l}\text { Section } \\
\text { of the } \\
\text { Law }\end{array}$ & Subject & Implementing Document & $\begin{array}{c}\text { Release } \\
\text { Date }\end{array}$ \\
\hline $\begin{array}{c}3131 \\
\text { (2of7) }\end{array}$ & $\begin{array}{l}\text { Payment adjustments for home health care -- Establishes a } 10 \text { percent cap on the } \\
\text { amount of reimbursement a home health provider can receive from outlier } \\
\text { payments and would reinstate an add-on payment for rural home health providers } \\
\text { from April 1, } 2010 \text { through } 2015 \text {. }\end{array}$ & $\begin{array}{l}\text { Guidance - Change Request } \\
\text { Regulation - HHA Proposed Rule } \\
\text { Regulation - HHA Final Rule }\end{array}$ & $\begin{array}{l}03 / 31 / 2010 \\
7 / 16 / 2010 \\
11 / 2 / 2010\end{array}$ \\
\hline $\begin{array}{c}3131 \\
\text { (7of7) }\end{array}$ & $\begin{array}{l}\text { Payment adjustments for home health care -- Reinstate an add-on payment for } \\
\text { rural home health providers from April 1, } 2010 \text { through } 2015\end{array}$ & $\begin{array}{l}\text { Guidance -- JSM } \\
\text { Guidance -- Change Request }\end{array}$ & $\begin{array}{l}04 / 08 / 2010 \\
04 / 23 / 2010\end{array}$ \\
\hline $\begin{array}{c}3132 \\
(3 \circ 3)\end{array}$ & $\begin{array}{l}\text { Hospice reform - Requires a hospice physician or nurse practitioner to have a face- } \\
\text { to-face encounter with the individual to determine continued eligibility for } \\
\text { hospice care prior to the } 180 \text { th day recertification and each subsequent } \\
\text { recertification and attests that such visit took place as established by the Secretary. }\end{array}$ & $\begin{array}{l}\text { Regulation - Home Health PPS } \\
\text { Proposed Rule } \\
\text { Regulation - HHA Final Rule }\end{array}$ & $\begin{array}{l}7 / 16 / 2010 \\
11 / 2 / 2010\end{array}$ \\
\hline 3134 & $\begin{array}{l}\text { Misvalued codes under the physician fee schedule -- Directs the Secretary to } \\
\text { regularly review fee schedule rates for physician services paid for by Medicare, } \\
\text { including services that have experienced high growth rates. Strengthens the } \\
\text { Secretary's authority to adjust fee schedule rates that are found to be misvalued or } \\
\text { inaccurate. } \\
\text { Eliminates the Practicing Physicians Advisory Council (PPAC). }\end{array}$ & $\begin{array}{l}\frac{\text { Regulation -- Physician Fee }}{\text { Schedule Proposed Rule }} \\
\text { Regulation - Physician Fee } \\
\text { Schedule Final Rule }\end{array}$ & $\begin{array}{l}06 / 25 / 2010 \\
11 / 2 / 2010\end{array}$ \\
\hline
\end{tabular}




\section{The Patient Protection and Affordable Care Act}

All CMS Provisions -- As of December 10, 2010

\begin{tabular}{|c|c|c|c|}
\hline $\begin{array}{l}\text { Section } \\
\text { of the } \\
\text { Law }\end{array}$ & Subject & Implementing Document & $\begin{array}{c}\text { Release } \\
\text { Date }\end{array}$ \\
\hline $\begin{array}{c}3135 \\
\text { (1of3) }\end{array}$ & $\begin{array}{l}\text { Modification of equipment utilization factor for advanced imaging services -- RB - } \\
\text { - } 1107 \text {-- Payment for Imaging Services -- Sets the assumed utilization rate at } 75 \\
\text { percent for the practice expense portion of advanced diagnostic imaging services. }\end{array}$ & $\begin{array}{l}\text { Regulation -- Physician Fee } \\
\text { Schedule Proposed Rule } \\
\text { Regulation - Physician Fee } \\
\text { Schedule Final Rule }\end{array}$ & $06 / 25 / 2010$ \\
\hline $\begin{array}{c}3135 \\
\text { (2of3) }\end{array}$ & $\begin{array}{l}\text { Modification of equipment utilization factor for advanced imaging services -- } \\
\text { Adjusts the technical component discount on single session imaging studies on } \\
\text { contiguous body parts from } 25 \text { percent to } 50 \text { percent. }\end{array}$ & $\begin{array}{l}\text { Regulation -- Physician Fee } \\
\text { Schedule Proposed Rule } \\
\text { Regulation - Physician Fee } \\
\text { Schedule Final Rule }\end{array}$ & $06 / 25 / 2010$ \\
\hline 3136 & $\begin{array}{l}\text { Revision of payment for power-driven wheelchairs -- Eliminates the option for } \\
\text { Medicare to purchase power-driven wheelchairs with a lump-sum payment at the } \\
\text { time the chair is supplied. Medicare would continue to make the same payments } \\
\text { for power-driven chairs over a 13-month period. Purchase option for complex } \\
\text { rehabilitative power wheelchairs would be maintained. }\end{array}$ & $\begin{array}{l}\text { Regulation -- Physician Fee } \\
\text { Schedule Proposed Rule } \\
\text { Regulation - Physician Fee } \\
\text { Schedule Final Rule }\end{array}$ & $06 / 25 / 2010$ \\
\hline $\begin{array}{c}3137 \\
\text { (1of3) }\end{array}$ & $\begin{array}{l}\text { Hospital wage index improvement -- Extends reclassifications under section } 508 \text { of } \\
\text { the Medicare Modernization Act (P.L 108-173) through the end of FY2011. Also } \\
\text { directs the Secretary to restore the average hourly wage comparison thresholds } \\
\text { used to determine hospital reclassifications to the percentages used as of } \\
\text { September } 30,2008 \text {. }\end{array}$ & $\begin{array}{l}\text { Guidance -- JSM } \\
\text { Guidance - Change Request } \\
\text { Regulation -Changes to the IPPS } \\
\text { Resulting from } 2011 \mathrm{HCR} \\
\text { Proposed Rule } \\
\text { Regulation - IPPS Final Rule }\end{array}$ & $\begin{array}{l}4 / 22 / 2010 \\
7 / 10 / 2010 \\
05 / 21 / 2010 \\
07 / 30 / 2010\end{array}$ \\
\hline
\end{tabular}




\section{The Patient Protection and Affordable Care Act}

All CMS Provisions -- As of December 10, 2010

\begin{tabular}{|c|c|c|c|}
\hline $\begin{array}{l}\text { Section } \\
\text { of the } \\
\text { Law }\end{array}$ & Subject & Implementing Document & $\begin{array}{l}\text { Release } \\
\text { Date }\end{array}$ \\
\hline $\begin{array}{l}3137 \\
\text { (2of3) }\end{array}$ & $\begin{array}{l}\text { Hospital wage index improvement -- Sec. 10317-- Revisions to extension of } \\
\text { Section } 508 \text { hospital provisions -- Clarifies the Secretary may only use wage data of } \\
\text { certain eligible hospitals in carrying out this provision if doing so does not result in } \\
\text { lower wage index adjustments for affected facilities. }\end{array}$ & $\begin{array}{l}\text { Guidance - JSM } \\
\text { Regulation - IPPS Proposed Rule } \\
\text { Regulation - IPPS Final Rule }\end{array}$ & $\begin{array}{l}4 / 22 / 2010 \\
04 / 19 / 2010 \\
07 / 30 / 2010\end{array}$ \\
\hline 3138 & $\begin{array}{l}\text { Treatment of certain cancer hospitals -- Directs the Secretary to study whether } \\
\text { existing cancer hospitals that are exempt from the inpatient prospective payment } \\
\text { system have costs under the outpatient prospective payment system (OPPS) that } \\
\text { exceed costs of other hospitals, and to make an appropriate payment adjustment } \\
\text { under OPPS based on that analysis. } \\
10324 \text {-- Protections for frontier states -- With respect to covered OPD services } \\
\text { furnished on or after January } 1,2011 \text {, the area wage adjustment factor applicable } \\
\text { under the payment system established under this subsection to any hospital } \\
\text { outpatient department which is located in a frontier State may not be less than } \\
\text { 1.00. }\end{array}$ & $\begin{array}{l}\text { Regulation - OPPS Proposed } \\
\text { Rule } \\
\text { Regulation - OPPS Final Rule }\end{array}$ & $11 / 2 / 2010$ \\
\hline 3139 & $\begin{array}{l}\text { Payment for biosimilar biological products -- Sets the add-on payment rate for } \\
\text { biosimilar products reimbursement under Medicare Part B at } 6 \text { percent of the } \\
\text { average sales price of the brand biological product. }\end{array}$ & $\begin{array}{l}\frac{\text { Regulation -- Physician Fee }}{\text { Schedule Proposed Rule }} \\
\text { Regulation - Physician Fee } \\
\text { Schedule Final Rule }\end{array}$ & $\begin{array}{l}06 / 25 / 2010 \\
11 / 2 / 2010\end{array}$ \\
\hline 3141 & Application of budget neutrality on a national basis in the calculation of the & $\begin{array}{l}\text { Federal Register Notice -- } \\
\text { Changes to the IPPS Resulting }\end{array}$ & $05 / 21 / 2010$ \\
\hline
\end{tabular}




\section{The Patient Protection and Affordable Care Act}

All CMS Provisions -- As of December 10, 2010

\begin{tabular}{|c|c|c|c|}
\hline $\begin{array}{l}\text { Section } \\
\text { of the } \\
\text { Law }\end{array}$ & Subject & Implementing Document & $\begin{array}{c}\text { Release } \\
\text { Date }\end{array}$ \\
\hline & $\begin{array}{l}\text { Medicare hospital wage index floor -- Starting on October } 1,2010 \text {, the provision } \\
\text { would require application of budget neutrality associated with the effect of the } \\
\text { imputed rural and rural floor to be applied on a national, rather than State-specific } \\
\text { basis through a uniform, national adjustment to the area wage index. }\end{array}$ & $\begin{array}{l}\text { from } 2010 \text { HCR Provisions } \\
\text { Regulation - IPPS Final Rule }\end{array}$ & $07 / 30 / 2010$ \\
\hline $\begin{array}{c}3201 \\
\text { (1of2) }\end{array}$ & $\begin{array}{l}\text { Medicare Advantage payment -- } \mathbf{R B} \text {-- } \mathbf{1 1 0 2} \text {-- Medicare Advantage payments -- } \\
\text { Freezes Medicare Advantage payments in } 2011 \text {. Benchmarks will vary from } 95 \% \text { of } \\
\text { Medicare spending in high-cost areas to } 115 \% \text { of Medicare spending in low-cost } \\
\text { areas. The changes will be phased-in over 3, } 5 \text { or } 7 \text { years, depending on the level of } \\
\text { payment reductions. }\end{array}$ & $\begin{array}{l}2011 \text { Call Letter } \\
\text { Regulation - Revisions to the } \\
\text { Parts C \& D Contract Years } \\
2012 \text { Proposed Rule }\end{array}$ & $\begin{array}{l}04-05-10 \\
11-10-10\end{array}$ \\
\hline $\begin{array}{c}3301 \\
\text { (1of3) }\end{array}$ & $\begin{array}{l}\text { Medicare coverage gap discount program -- Requires drug manufacturers to } \\
\text { provide a } 50 \text { percent discount to Part D beneficiaries for brand-name drugs and } \\
\text { biologics purchased during the coverage gap beginning January } 1,2011 \text {. }\end{array}$ & $\begin{array}{l}\text { Guidance -- HPMS } \\
\text { Federal Register Notice } \\
\text { Regulation - Revisions to the } \\
\text { Parts C \& D Contract Years } \\
2012 \text { Proposed Rule }\end{array}$ & $\begin{array}{l}4 / 30 / 2010 \\
05 / 21 / 2010 \\
11-10-10\end{array}$ \\
\hline $\begin{array}{c}3301 \\
\text { (2of3) }\end{array}$ & $\begin{array}{l}\text { Medicare coverage gap discount program -- Requires the Secretary establish a } \\
\text { model agreement for use under the program in consultation with manufacturers } \\
\text { and allow for comment on such model agreement. }\end{array}$ & Federal Register Notice & $05-21-10$ \\
\hline
\end{tabular}




\section{The Patient Protection and Affordable Care Act}

All CMS Provisions -- As of December 10, 2010

\begin{tabular}{|c|c|c|c|}
\hline $\begin{array}{l}\text { Section } \\
\text { of the } \\
\text { Law }\end{array}$ & Subject & Implementing Document & $\begin{array}{c}\text { Release } \\
\text { Date }\end{array}$ \\
\hline $\begin{array}{c}3401 \\
\text { (1of3) }\end{array}$ & $\begin{array}{l}\text { Revision of certain market basket updates and incorporation of productivity } \\
\text { improvements into market basket updates that do not include such improvements -- } \\
\text { Incorporates a productivity adjustment into the market basket update for inpatient } \\
\text { hospitals, home health providers, skilled nursing facilities, hospice providers, inpatient } \\
\text { psychiatric facilities, long-term care hospitals and inpatient rehabilitation facilities } \\
\text { beginning in various years and implements additional market basket reductions for certain } \\
\text { providers. It would also incorporate a productivity adjustment into payment updates for } \\
\text { Part B providers who do not already have such an adjustment. } \\
\text { Sec. } 10319 \text {-- Revisions to market basket adjustments -- Modifies market adjustments for } \\
\text { inpatient hospitals, inpatient rehabilitation facilities, inpatient psychiatric hospitals and } \\
\text { outpatient hospitals in } 2012 \text { and } 2013 \text { and for long-term care hospitals in } 2011,2012 \text { and } \\
2013 . \text { Also, modifies market basket adjustments for home health providers in } 2013 \text { and } \\
\text { hospice providers in } 2013 \text { through } 2019 \text {. } \\
\text { RB -- } 1105 \text {-- Market basket updates-- Revises the hospital market basket reduction that is } \\
\text { in addition to the productivity adjustment as follows: -0.3 in FY14 and -0.75 in FY17, FY18 } \\
\text { and FY19. Removes Senate provision that eliminates the additional market basket for } \\
\text { hospitals based on coverage levels. Providers affected are inpatient hospitals, long-term } \\
\text { care hospitals, inpatient rehabilitation facilities, psychiatric hospitals and outpatient } \\
\text { hospitals. }\end{array}$ & $\begin{array}{l}\text { Guidance -- JSM (IRF,SNF,IPPS, } \\
\text { LTCH, OPPS, HH,) } \\
\text { Guidance -- JSM (IPPS, LTCH) } \\
\text { Regulation - IPPS Proposed Rules } \\
\text { Regulation - PFS and OPPS } \\
\text { Proposed Rule } \\
\text { Federal Register Notice - } \\
\text { Changes to the OPPS/ASC } \\
\text { Resulting from } 2010 \text { HCR } \\
\text { Provisions } \\
\text { Regulation - HH Proposed Rule } \\
\text { Regulation - IPPS Final Rules } \\
\text { Psych PPS Notice } \\
\text { Regulation - PFS and OPPS Final } \\
\text { Rule } \\
\text { Regulation - HH Final Rule }\end{array}$ & $\begin{array}{c}7 / 16 / 2010 \\
07 / 30 / 2010 \\
5 / 1 / 2010 \\
11 / 2 / 2010 \\
11 / 2 / 10\end{array}$ \\
\hline $\begin{array}{c}4103 \\
\text { (1of4) }\end{array}$ & $\begin{array}{l}\text { Medicare coverage of annual wellness visit providing a personalized prevention } \\
\text { plan -- Provides coverage under Medicare, with no co-payment or deductible, for }\end{array}$ & $\begin{array}{l}\text { Regulation -- Physician Fee } \\
\text { Schedule Proposed Rule }\end{array}$ & $06 / 25 / 2010$ \\
\hline
\end{tabular}




\section{The Patient Protection and Affordable Care Act}

All CMS Provisions -- As of December 10, 2010

\begin{tabular}{|c|c|c|c|}
\hline $\begin{array}{l}\text { Section } \\
\text { of the } \\
\text { Law }\end{array}$ & Subject & Implementing Document & $\begin{array}{c}\text { Release } \\
\text { Date }\end{array}$ \\
\hline & $\begin{array}{l}\text { an annual wellness visit and personalized prevention plan services. Such services } \\
\text { would include a comprehensive health risk assessment. The personalized } \\
\text { prevention plan would take into account the findings of the health risk assessment } \\
\text { and include elements such as: a five- to ten-year screening schedule; a list of } \\
\text { identified risk factors and conditions and a strategy to address them; health advice } \\
\text { and referral to education and preventive counseling community-based } \\
\text { interventions to address modifiable risk factors such as physical activity, smoking, } \\
\text { and nutrition. }\end{array}$ & $\begin{array}{l}\text { Regulation - Physician Fee } \\
\text { Schedule Final Rule }\end{array}$ & $11 / 2 / 2010$ \\
\hline $\begin{array}{c}4103 \\
\text { (2of4) }\end{array}$ & $\begin{array}{l}\text { Medicare coverage of annual wellness visit providing a personalized prevention } \\
\text { plan -- Requires the Secretary establish publicly available guidelines for health risk } \\
\text { assessments. } \\
\text { Requires the Secretary establish standards for interactive telephonic or webbased } \\
\text { programs used to furnish health risk assessments. }\end{array}$ & $\begin{array}{l}\text { Regulation -- Physician Fee } \\
\text { Schedule Proposed Rule } \\
\text { Regulation - Physician Fee } \\
\text { Schedule Final Rule }\end{array}$ & $\begin{array}{r}06 / 25 / 2010 \\
11 / 2 / 2010\end{array}$ \\
\hline 4104 & $\begin{array}{l}\text { Removal of barriers to preventive services in Medicare -- This section would waive } \\
\text { beneficiary coinsurance requirements for most preventive services, requiring } \\
\text { Medicare to cover } 100 \text { percent of the costs. Services for which no coinsurance or } \\
\text { deductible would be required are the personalized prevention plan services and } \\
\text { any covered preventive service if it is recommended with a grade of A or B by the } \\
\text { U.S. Preventive Services Task Force. } \\
\text { Sec. } 10406 \text {-- Amendment relating to waiving coinsurance for preventive services } \\
\text { - Clarifies that Medicare beneficiaries do not have to pay coinsurance (including }\end{array}$ & $\begin{array}{l}\text { Regulation -- Physician Fee } \\
\text { Schedule Proposed Rule } \\
\text { Regulation - Physician Fee } \\
\text { Schedule Final Rule } \\
\text { Guidance - Change Request } \\
\text { Regulation - Revisions to the } \\
\text { Parts C \& D Contract Year }\end{array}$ & $\begin{array}{l}11 / 2 / 2010 \\
11 / 10 / 10\end{array}$ \\
\hline
\end{tabular}




\section{The Patient Protection and Affordable Care Act}

All CMS Provisions -- As of December 10, 2010

\begin{tabular}{|c|c|c|c|}
\hline $\begin{array}{l}\text { Section } \\
\text { of the } \\
\text { Law }\end{array}$ & Subject & Implementing Document & $\begin{array}{c}\text { Release } \\
\text { Date }\end{array}$ \\
\hline & co-pays and deductibles) for preventive services delivered in all settings. & 2012 Proposed Rule & \\
\hline $\begin{array}{c}4105 \\
\text { (2of3) }\end{array}$ & $\begin{array}{l}\text { Evidence-based coverage of preventive services in Medicare -- } 10501 \text { - (3)(A) -- } \\
\text { Directs the Secretary to require FQHCs to submit to the Secretary such information } \\
\text { require in order to develop and implement the FQHC prospective payment system. }\end{array}$ & $\begin{array}{l}\text { Regulation -- Physician Fee } \\
\text { Schedule Proposed Rule } \\
\text { Regulation - Physician Fee } \\
\text { Schedule Final Rule }\end{array}$ & $06 / 25 / 2010$ \\
\hline $\begin{array}{c}5104 \\
\text { (2of2) }\end{array}$ & $\begin{array}{l}\text { Sec. } 10501 \text {-- Amendments to Title V -- Interagency task force to assess and } \\
\text { improve access to health care in the State of Alaska - requires the Task force } \\
\text { submit a report to Congress. }\end{array}$ & RTC & 9/17/10 \\
\hline 5501 & $\begin{array}{l}\text { Expanding access to primary care services and general surgery service -- Beginning } \\
\text { in 2011, provides primary care practitioners, as well as general surgeons practicing } \\
\text { in health professional shortage areas, with a } 10 \text { percent Medicare payment bonus } \\
\text { for five years. Half of the cost of the bonuses would be offset through an across- } \\
\text { the-board reduction in all other services. }\end{array}$ & $\begin{array}{l}\text { Guidance - Change Request } \\
\text { Regulation -- Physician Fee } \\
\underline{\text { Schedule Proposed Rule }} \\
\text { Regulation - Physician Fee } \\
\text { Schedule Final Rule }\end{array}$ & $\begin{array}{c}6-4-10 \\
06 / 25 / 2010\end{array}$ \\
\hline 5503 & $\begin{array}{l}\text { Distribution of additional residency positions -- Beginning July } 1,2011 \text {, directs the } \\
\text { Secretary to redistribute residency positions that have been unfilled for the prior } \\
\text { three cost reports and directs those slots for training of primary care physicians. In } \\
\text { distributing the residency slots under this section, special preference will be given } \\
\text { to programs located in States with a low physician resident to general population } \\
\text { ratio and to programs located in States with the highest ratio of population living in }\end{array}$ & $\begin{array}{l}\text { Regulation -- OPPS Proposed Rule } \\
\text { Regulation - OPPS Final Rule }\end{array}$ & 7-2-10 \\
\hline
\end{tabular}




\section{The Patient Protection and Affordable Care Act}

All CMS Provisions -- As of December 10, 2010

\begin{tabular}{|c|c|c|c|}
\hline $\begin{array}{l}\text { Section } \\
\text { of the } \\
\text { Law }\end{array}$ & Subject & Implementing Document & $\begin{array}{c}\text { Release } \\
\text { Date }\end{array}$ \\
\hline & a health professional shortage area (HPSA) relative to the general population. & & \\
\hline 5504 & $\begin{array}{l}\text { Counting resident time in outpatient settings and allowing flexibility for jointly } \\
\text { operated residency training programs -- Modifies rules governing when hospitals } \\
\text { can receive indirect medical education (IME) and direct graduate medical } \\
\text { education (DGME) funding for residents who train in a non-provider setting so that } \\
\text { any time spent by the resident in a non-provider setting shall be counted toward } \\
\text { DGME and IME if the hospital incurs the costs of the stipends and fringe benefits. }\end{array}$ & $\begin{array}{l}\text { Regulation -- OPPS Proposed Rule } \\
\text { Regulation - OPPS Final Rule }\end{array}$ & $\begin{array}{l}7-2-10 \\
11-2-10\end{array}$ \\
\hline 5505 & $\begin{array}{l}\text { Rules for counting resident time for didactic and scholarly activities and other } \\
\text { activities -- Modifies current law to allow hospitals to count resident time spent in } \\
\text { didactic conferences toward IME costs in the provider (i.e., hospital) setting and } \\
\text { toward DGME in the non-provider (i.e., non-hospital) setting. } \\
\text { Sec. } 10501 \text {-- Amendments to Title } V \text { - (j) Technical corrections to the rules for } \\
\text { counting resident time for didactic and scholarly activities and other activities -- } \\
\text { Clarifies that the Secretary is not required to reopen certain settled cost reports in } \\
\text { applying changes to Medicare graduate medical education payment rules related } \\
\text { to didactic training. }\end{array}$ & $\begin{array}{l}\text { Regulation -- OPPS Proposed Rule } \\
\text { Regulation - OPPS Final Rule }\end{array}$ & $\begin{array}{l}7-2-10 \\
11-2-10\end{array}$ \\
\hline 5506 & $\begin{array}{l}\text { Preservation of resident cap positions from closed hospitals -- Directs the } \\
\text { Secretary to redistribute medical residency slots from a hospital that closes on or } \\
\text { after the date that is two years before enactment of this legislation based on } \\
\text { certain criteria. }\end{array}$ & $\begin{array}{l}\text { Regulation -- OPPS Proposed Rule } \\
\text { Regulation - OPPS Final Rule }\end{array}$ & $\begin{array}{l}7-2-10 \\
11-2-10\end{array}$ \\
\hline
\end{tabular}




\section{The Patient Protection and Affordable Care Act}

All CMS Provisions -- As of December 10, 2010

\begin{tabular}{|c|c|c|c|}
\hline $\begin{array}{l}\text { Section } \\
\text { of the } \\
\text { Law }\end{array}$ & Subject & Implementing Document & $\begin{array}{l}\text { Release } \\
\text { Date }\end{array}$ \\
\hline $\begin{array}{c}6001 \\
\text { (1of3) }\end{array}$ & $\begin{array}{l}\text { Limitation on Medicare exception to the prohibition on certain physician referrals } \\
\text { for hospitals -- Prohibits physician-owned hospitals that do not have a Medicare } \\
\text { provider agreement in effect on December 31, } 2010 \text { from furnishing services } \\
\text { pursuant to referrals made by physician owners or investors (known as "self- } \\
\text { referral"). Hospitals that have physician owners or investors and a provider } \\
\text { agreement in effect on December } 31,2010 \text { may continue to access exceptions to } \\
\text { the self-referral prohibition if certain requirements are met addressing conflicts of } \\
\text { interest, bona fide investments, and patient safety issues, as well as new disclosure } \\
\text { and reporting requirements. } \\
\text { Sec } 10601 \text {-- Revisions to limitation on Medicare exception to the prohibition on } \\
\text { certain physician referrals for hospitals -- changed dates that were then changed } \\
\text { by RB. } \\
\text { RB -- } 1106 \text {-- Physician ownership -referral -- Changes to December } 31,2010 \text { the } \\
\text { date after which physician ownership of hospitals to which they self refer is } \\
\text { prohibited and provides a limited exception to the growth restrictions for } \\
\text { grandfathered physician owned hospitals that treat the highest percentage of } \\
\text { Medicaid patients in their county (and are not the sole hospital in a county). }\end{array}$ & $\begin{array}{l}\text { Regulation -- OPPS Proposed Rule } \\
\text { Regulation - OPPS Final Rule }\end{array}$ & $\begin{array}{l}7-2-10 \\
11-2-10\end{array}$ \\
\hline 6003 & $\begin{array}{l}\text { Disclosure requirements for in-office ancillary services exception to the } \\
\text { prohibition on physician self-referral for certain imaging services -- Adds an } \\
\text { additional requirement to the Medicare in-office ancillary exception that requires } \\
\text { the referring physician to inform the patient in writing that the individual may } \\
\text { obtain the specified service from a person other than the referring physician, a }\end{array}$ & $\begin{array}{l}\frac{\text { Regulation -- Physician Fee }}{\text { Schedule Proposed Rule }} \\
\text { Regulation - Physician Fee }\end{array}$ & $\begin{array}{c}06 / 25 / 2010 \\
11-2-10\end{array}$ \\
\hline
\end{tabular}




\section{The Patient Protection and Affordable Care Act}

All CMS Provisions -- As of December 10, 2010

\begin{tabular}{|c|c|c|c|}
\hline $\begin{array}{l}\text { Section } \\
\text { of the } \\
\text { Law }\end{array}$ & Subject & Implementing Document & $\begin{array}{c}\text { Release } \\
\text { Date }\end{array}$ \\
\hline & $\begin{array}{l}\text { physician who is a member of the same group practice as the referring physician, } \\
\text { or an individual who is directly supervised by the physician or by another physician } \\
\text { in the group practice. }\end{array}$ & Schedule Final Rule & \\
\hline 6111 & $\begin{array}{l}\text { Civil money penalties -- Provides the Secretary with authority to reduce civil } \\
\text { monetary penalties (CMPs) from the level that they would otherwise be by } 50 \\
\text { percent for certain facilities that self-report and promptly correct deficiencies } \\
\text { within ten calendar days of imposition. For CMPs that are cited at the level of } \\
\text { actual harm and immediate jeopardy, the Secretary would be provided with the } \\
\text { authority to place CMPs in an escrow account following completion of the informal } \\
\text { dispute resolution process, or the date that is } 90 \text { days after the date of the } \\
\text { imposition of the CMP, whichever is earlier. If the facility's appeal is successful, the } \\
\text { CMP, with interest, would be returned to the facility. If the appeal is unsuccessful, } \\
\text { some portion of the proceeds may be used to fund activities that benefit facility } \\
\text { residents. }\end{array}$ & $\begin{array}{l}\text { Regulation -- CMP Reduction for } \\
\text { Self-Reporting Proposed Rule } \\
\text { State Medicaid informational } \\
\text { Bulletin }\end{array}$ & $7 / 12 / 2010$ \\
\hline $\begin{array}{c}6201 \\
\text { (1of2) }\end{array}$ & $\begin{array}{l}\text { Nationwide program for National and State background checks on direct patient } \\
\text { access employees of long-term care facilities and providers -- Requires the } \\
\text { Secretary to establish a nationwide program for national and State background } \\
\text { checks on direct patient access employees of certain long-term supports and } \\
\text { services facilities or providers. This program is based on the background check pilot } \\
\text { program in the Medicare Modernization Act. }\end{array}$ & Grant Solicitation & $06 / 15 / 2010$ \\
\hline
\end{tabular}




\section{The Patient Protection and Affordable Care Act}

All CMS Provisions -- As of December 10, 2010

\begin{tabular}{|c|c|c|c|}
\hline $\begin{array}{l}\text { Section } \\
\text { of the } \\
\text { Law }\end{array}$ & Subject & Implementing Document & $\begin{array}{l}\text { Release } \\
\text { Date }\end{array}$ \\
\hline 6401 & $\begin{array}{l}\text { Provider screening and other enrollment requirements under Medicare, Medicaid, and CHIP -- Provider } \\
\text { screening -- Requires that the Secretary, in consultation with the OIG, establish procedures for screening } \\
\text { providers and suppliers participating in Medicare, Medicaid, and CHIP. Requires the Secretary to } \\
\text { determine the level of screening according to the risk of fraud, waste, and abuse with respect to each } \\
\text { category of provider or supplier. At a minimum, all providers. The Secretary would have the authority to } \\
\text { impose additional screening measures based on risk, including fingerprinting, criminal background checks, } \\
\text { multi-State data base inquiries, and random or unannounced site visits. }\end{array}$ & $\begin{array}{l}\text { Regulation - Program Integrity for } \\
\text { Provider-Supplier Proposed Rule } \\
\text { CPI -CMCS Informational Bulletin }\end{array}$ & $69 / 17 / 2010$ \\
\hline $\begin{array}{c}6402 \\
(1 \mathrm{of3})\end{array}$ & $\begin{array}{l}\text { Enhanced Medicare and Medicaid program integrity provisions -- } \\
\text { National Provider Identifier -- Requires the Secretary to issue a regulation mandating } \\
\text { that all Medicare, Medicaid, and CHIP providers include their NPI on enrollment } \\
\text { applications. }\end{array}$ & $\begin{array}{l}\text { Regulation - Changes in Provider } \\
\text { and Supplier Enrollment, Ordering } \\
\text { and Referring, and Documentation } \\
\text { Requirements, etc. Interim Final Rule } \\
\text { (to address NPI) } \\
\text { Regulation - Program Integrity for } \\
\text { Provider-Supplier Proposed Rule }\end{array}$ & $09 / 17 / 10$ \\
\hline 6404 & $\begin{array}{l}\text { Maximum period for submission of Medicare claims reduced to not more than } 12 \\
\text { months -- Beginning January 2010, the maximum period for submission of } \\
\text { Medicare claims would be reduced to not more than } 12 \text { months. }\end{array}$ & $\begin{array}{l}\text { Guidance -- JSM } \\
\text { Guidance -- Change Request } \\
\frac{\text { Regulation -- Physician Fee }}{\text { Schedule Proposed Rule }} \\
\text { Regulation - Physician Fee } \\
\text { Schedule Final Rule }\end{array}$ & $\begin{array}{l}3-31-10 \\
5-7-10 \\
6-25-10 \\
11-2-10\end{array}$ \\
\hline 6405 & $\begin{array}{l}\text { Physicians who order items or services required to be Medicare enrolled } \\
\text { physicians or eligible professionals -- Requires durable medical equipment (DME) }\end{array}$ & $\begin{array}{l}\text { Regulation - Changes in Provider } \\
\text { and Supplier Enrollment, Ordering }\end{array}$ & $04 / 30 / 2010$ \\
\hline
\end{tabular}




\section{The Patient Protection and Affordable Care Act}

All CMS Provisions -- As of December 10, 2010

\begin{tabular}{|c|c|c|c|}
\hline $\begin{array}{l}\text { Section } \\
\text { of the } \\
\text { Law }\end{array}$ & Subject & Implementing Document & $\begin{array}{c}\text { Release } \\
\text { Date }\end{array}$ \\
\hline & $\begin{array}{l}\text { or home health services to be ordered by a Medicare physician enrolled in the } \\
\text { Medicare program. The Secretary would have the authority to extend these } \\
\text { requirements to other Medicare items and services to reduce fraud, waste, and } \\
\text { abuse. } \\
\text { Sec } 10604 \text {-- Technical Corrections to Section } 6405 \text {-- Clarifies that this expansion of } \\
\text { DME requirements applies to those enrolled in Sec. 1866(j) of the SSA and not also } \\
\text { those referred to in Sec. } 1848(\mathrm{k})(3)(B) \text { of the SSA. }\end{array}$ & $\begin{array}{l}\begin{array}{l}\text { and Referring, and Documentation } \\
\text { Requirements, etc. Interim Final Rule } \\
\text { (to address NPI) }\end{array} \\
\text { Guidance -- Press Release } \\
\text { Regulation - Program Integrity for } \\
\text { Provider-Supplier Proposed Rule }\end{array}$ & $\begin{array}{l}6 / 30 / 2010 \\
09 / 17 / 10\end{array}$ \\
\hline $\begin{array}{c}6406 \\
\text { (1of2) }\end{array}$ & $\begin{array}{l}\text { Requirement for physicians to provide documentation on referrals to programs at } \\
\text { high risk of waste and abuse -- Beginning January } 1,2010 \text {, the Secretary would } \\
\text { have the authority to disenroll, for no more than one year, a Medicare enrolled } \\
\text { physician or supplier that fails to maintain and provide access to written orders or } \\
\text { requests for payment for DME, certification for home health services, or referrals } \\
\text { for other items and services. }\end{array}$ & $\begin{array}{l}\text { Regulation - Changes in Provider } \\
\text { and Supplier Enrollment, Ordering } \\
\text { and Referring, and Documentation } \\
\text { Requirements, etc. Interim Final Rule } \\
\text { (to address NPI) }\end{array}$ & $04 / 30 / 2010$ \\
\hline $\begin{array}{c}6407 \\
\text { (1of2) }\end{array}$ & $\begin{array}{l}\text { Face-to-face encounter with patient required before physicians may certify } \\
\text { eligibility for home health services or durable medical equipment under Medicare } \\
\text {-- Requires physicians to have a face-to-face encounter with the individual prior to } \\
\text { issuing a certification for home health services. The Secretary would be authorized } \\
\text { to apply the face-to-face encounter requirement to other items and services based } \\
\text { upon a finding that doing so would reduce the risk of fraud, waste, and abuse. This } \\
\text { provision also applies to Medicaid. } \\
\text { Sec. } 10605 \text {-- Certain other providers permitted to conduct face-to-face encounter }\end{array}$ & $\begin{array}{l}\text { Guidance -- Change Request } \\
\text { Regulation - Home Health Proposed } \\
\text { Rule } \\
\text { Regulation - Home Health Final Rule }\end{array}$ & $\begin{array}{r}11 / 2 / 2010 \\
07 / 16 / 2010 \\
11 / 02 / 2010\end{array}$ \\
\hline
\end{tabular}




\section{The Patient Protection and Affordable Care Act}

All CMS Provisions -- As of December 10, 2010

\begin{tabular}{|c|c|c|c|}
\hline $\begin{array}{l}\text { Section } \\
\text { of the } \\
\text { Law }\end{array}$ & Subject & Implementing Document & $\begin{array}{c}\text { Release } \\
\text { Date }\end{array}$ \\
\hline & $\begin{array}{l}\text { for home health services -- Clarifies that the face-to-face encounter required prior } \\
\text { to certification for home health services may be performed by a physician, nurse } \\
\text { practitioner, clinical nurse specialist, certified nurse-midwife, or physician assistant. }\end{array}$ & & \\
\hline $\begin{array}{c}6409 \\
\text { (1of2) }\end{array}$ & $\begin{array}{l}\text { Medicare self-referral disclosure protocol -- Within six months of enactment, the } \\
\text { Secretary, in cooperation with the HHS OIG, would be required to establish a self- } \\
\text { referral disclosure protocol to enable health care providers and suppliers to } \\
\text { disclose actual or potential violations of the physician self-referral law. }\end{array}$ & Guidance - Web posting & $09 / 23 / 2010$ \\
\hline $\begin{array}{c}6410 \\
\text { (1of2) }\end{array}$ & $\begin{array}{l}\text { Adjustments to the Medicare durable medical equipment, prosthetics, orthotics, } \\
\text { and supplies competitive acquisition program -- Requires the Secretary to expand } \\
\text { the number of areas to be included in round two of the competitive bidding } \\
\text { program from } 79 \text { of the largest metropolitan statistical areas (MSAs) to } 100 \text { of the } \\
\text { largest MSAs. }\end{array}$ & $\begin{array}{l}\frac{\text { Regulation -- Physician Fee }}{\text { Schedule Proposed Rule }} \\
\text { Regulation - Physician Fee } \\
\text { Schedule Final Rule }\end{array}$ & $06 / 25 / 2010$ \\
\hline $\begin{array}{l}6410 \\
(2 \circ 2)\end{array}$ & $\begin{array}{l}\text { Adjustments to the Medicare durable medical equipment, prosthetics, orthotics, } \\
\text { and supplies competitive acquisition program -- Requires the Secretary to use } \\
\text { competitively bid prices in all areas by } 2016 \text {. }\end{array}$ & $\begin{array}{l}\text { Regulation -- Physician Fee } \\
\text { Schedule Proposed Rule } \\
\text { Regulation - Physician Fee } \\
\text { Schedule Final Rule }\end{array}$ & $06 / 25 / 2010$ \\
\hline 6501 & $\begin{array}{l}\text { Termination of provider participation under Medicaid if terminated under } \\
\text { Medicare or other State plan-- Requires States to terminate the participation of } \\
\text { individuals or entities from their Medicaid programs if the participation individuals } \\
\text { or entities were terminated from Medicare or another State's Medicaid program. }\end{array}$ & $\begin{array}{l}\text { Regulation - Program Integrity for } \\
\text { Provider-Supplier Proposed Rule }\end{array}$ & $09 / 17 / 2010$ \\
\hline
\end{tabular}




\section{The Patient Protection and Affordable Care Act}

All CMS Provisions -- As of December 10, 2010

\begin{tabular}{|c|c|c|c|}
\hline $\begin{array}{l}\text { Section } \\
\text { of the } \\
\text { Law }\end{array}$ & Subject & Implementing Document & $\begin{array}{c}\text { Release } \\
\text { Date }\end{array}$ \\
\hline 6506 & $\begin{array}{l}\text { Overpayments -- Extends the period for States to recover overpayments due to } \\
\text { fraud to one year after date of discovery of the overpayment, before an } \\
\text { adjustment is made to the federal payment. If the State has not recovered the } \\
\text { overpayment due to fraud within one year of discovery because there has not been } \\
\text { a final determination of the overpayment amount, no adjustment shall be made in } \\
\text { the Federal payment to such State on account of such overpayment (or portion } \\
\text { thereof) before the date that is } 30 \text { days after the date on which a final judgment } \\
\text { (including, if applicable, a final determination on an appeal) is made. } \\
\text { The Secretary shall promulgate regulations that require States to correct Federally } \\
\text { identified claims overpayments, of an ongoing or recurring nature, with new } \\
\text { Medicaid Management Information System (MMIS) edits, audits, or other } \\
\text { appropriate corrective action. }\end{array}$ & SMD Letter & $7-13-2010$ \\
\hline $\begin{array}{c}6507 \\
(1 \circ 2)\end{array}$ & $\begin{array}{l}\text { Mandatory State use of national correct coding initiative -- Requires States to } \\
\text { make their MMIS methodologies compatible with Medicare's national correct } \\
\text { coding initiative (NCCl) that promotes correct coding and controls improper coding. }\end{array}$ & SMD Letter & $9 / 1 / 2010$ \\
\hline
\end{tabular}




\section{The Patient Protection and Affordable Care Act}

All CMS Provisions -- As of December 10, 2010

\begin{tabular}{|c|c|c|c|}
\hline $\begin{array}{l}\text { Section } \\
\text { of the } \\
\text { Law }\end{array}$ & Subject & Implementing Document & $\begin{array}{c}\text { Release } \\
\text { Date }\end{array}$ \\
\hline $\begin{array}{c}6703 \\
\text { (1of9) }\end{array}$ & $\begin{array}{l}\text { Elder Justice -- Requires the Secretary of HHS, in consultation with the } \\
\text { Departments of Justice and Labor, to award grants and carry out activities that } \\
\text { provide greater protection to those individuals seeking care in facilities that } \\
\text { provide long-term services and supports and provide greater incentives for } \\
\text { individuals to train and seek employment at such facilities. Owners, operators, and } \\
\text { certain employees of these facilities would be required to report suspected crimes } \\
\text { committed at a facility. Owners or operators of such facilities would also be } \\
\text { required to submit to the Secretary and to the State written notification of an } \\
\text { impending closure of a facility within } 60 \text { days prior to the closure. In the notice, the } \\
\text { owner or operator would be required to include a plan for transfer and adequate } \\
\text { relocation of all residents. }\end{array}$ & Grant Solicitation & $07-15-10$ \\
\hline $\begin{array}{l}10201 \\
\text { (1of2) }\end{array}$ & $\begin{array}{l}\text { Amendments to the Social Security Act and Title II of this Act - Increases the } \\
\text { transparency of the Medicaid waiver development and approval processes, at the } \\
\text { State and federal levels by Requiring the Secretary to promulgate regulations } \\
\text { relating to the application and renewals of a demonstration project that provides } \\
\text { for a process for public hearings. }\end{array}$ & Regulation - Proposed Rule & $09 / 17 / 2010$ \\
\hline 10324 & $\begin{array}{l}\text { Protections for frontier states -- Starting in fiscal year } 2011 \text {, establishes hospital } \\
\text { wage index and geographic practice expense floors for hospitals and physicians } \\
\text { located in states in which at least } 50 \text { percent of the counties in the state are } \\
\text { frontier. }\end{array}$ & $\begin{array}{l}\text { Regulation -- OPPS and Physician } \\
\text { Fee Schedule Proposed Rule } \\
\text { Federal Register Notice -- } \\
\text { Changes to the IPPS Resulting } \\
\text { from } 2010 \text { HCR Provisions }\end{array}$ & $\begin{array}{l}-2-10 \\
5-21-10\end{array}$ \\
\hline
\end{tabular}




\section{The Patient Protection and Affordable Care Act}

All CMS Provisions -- As of December 10, 2010

\begin{tabular}{|c|c|c|c|}
\hline $\begin{array}{l}\text { Section } \\
\text { of the } \\
\text { Law }\end{array}$ & Subject & Implementing Document & $\begin{array}{c}\text { Release } \\
\text { Date }\end{array}$ \\
\hline & & $\begin{array}{l}\text { Regulation - OPPS and } \\
\text { Physician Fee Schedule Final } \\
\text { Rule }\end{array}$ & $11-2-10$ \\
\hline 10325 & $\begin{array}{l}\text { Revision to skilled nursing facility prospective payment system --Delays } \\
\text { implementation of certain skilled nursing facility "RUGs-IV" payment system } \\
\text { changes by one year to October 1, 2011. Beginning October 1, 2010, the Secretary } \\
\text { shall implement changes specific to therapy furnished on a concurrent basis that is } \\
\text { a component of RUG-IV and changes to the look-back period to ensure that only } \\
\text { those services furnished after admission to a SNF are used as factors in } \\
\text { determining a case-mix classification. }\end{array}$ & $\begin{array}{l}\text { Federal Register Notice -- SNF } \\
\text { PPS }\end{array}$ & 07-19-10 \\
\hline 10327 & $\begin{array}{l}\text { Improvements to the Physician Quality Reporting System -- Provides an additional } \\
0.5 \text { percent Medicare payment bonus to physicians who successfully report quality } \\
\text { measures to CMS via a qualified Maintenance of Certification program. Eliminates } \\
\text { the MA Regional Plan Stabilization Fund. }\end{array}$ & $\begin{array}{l}\text { Regulation - Revisions to the } \\
\text { Parts C \& D Contract Years } 2012 \\
\text { Proposed Rule }\end{array}$ & $11-10-10$ \\
\hline 10328 & $\begin{array}{l}\text { Improvement in Part D medication therapy management (MTM) programs -- } \\
\text { Requires Part D prescription drug plans to include a comprehensive review of } \\
\text { medications (either in person or through telehealth technology) and a written } \\
\text { summary of the review as part of their medication therapy management programs. } \\
\text { Plans must also enroll beneficiaries who qualify on a quarterly basis and allow for } \\
\text { opt out. }\end{array}$ & $\begin{array}{l}\text { Regulation - Revisions to the } \\
\text { Parts C \& D Contract Years } 2012 \\
\text { Proposed Rule }\end{array}$ & $11-10-10$ \\
\hline
\end{tabular}




\section{The Patient Protection and Affordable Care Act}

All CMS Provisions -- As of December 10, 2010

\begin{tabular}{|c|c|c|c|}
\hline $\begin{array}{l}\text { Section } \\
\text { of the } \\
\text { Law }\end{array}$ & Subject & Implementing Document & $\begin{array}{l}\text { Release } \\
\text { Date }\end{array}$ \\
\hline 10332 & $\begin{array}{l}\text { Availability of Medicare data for performance measurement -- Authorizes the } \\
\text { release and use of standardized extracts of Medicare claims data to measure the } \\
\text { performance of providers and suppliers in ways that protect patient privacy and in } \\
\text { accordance with other requirements. }\end{array}$ & $\begin{array}{l}\text { Federal Register Notice -- Medicare } \\
\text { Program; Listening Session } \\
\text { Regarding the Availability of } \\
\text { Medicare Data for Performance } \\
\text { Measurement, September } 20,2010 \text { - } \\
-(C M S-0031-N)\end{array}$ & $08 / 27 / 2010$ \\
\hline
\end{tabular}

